Research Article

\title{
Woody Species Diversity and Vegetation Structure of Wurg Forest, Southwest Ethiopia
}

\author{
Girma $\mathrm{Boz}^{1}$ and Melesse Maryo $\mathbb{D D}^{2}$ \\ ${ }^{1}$ Department of Biology, Mizan Tepi University, Tepi, Ethiopia \\ ${ }^{2}$ Ethiopian Biodiversity Institute, Addis Ababa, P. O. B-30726, Ethiopia \\ Correspondence should be addressed to Melesse Maryo; tsegishlegesse@gmail.com
}

Received 17 April 2020; Revised 18 September 2020; Accepted 29 September 2020; Published 19 October 2020

Academic Editor: Ahmad A. Omar

Copyright (c) 2020 Girma Boz and Melesse Maryo. This is an open access article distributed under the Creative Commons Attribution License, which permits unrestricted use, distribution, and reproduction in any medium, provided the original work is properly cited.

\begin{abstract}
This study was aimed to determine woody species composition, diversity, and vegetation structure and to investigate major threats to Wurg forest, southwest Ethiopia. In order to collect vegetation data, $64\left(400 \mathrm{~m}^{2}\right)$ sample plots from eight transect lines were employed. The distances between transect lines and plots were $400 \mathrm{~m}$ and $200 \mathrm{~m}$, respectively. DBH of woody species $>2.5 \mathrm{~cm}$ and the height $>2 \mathrm{~m}$ were measured and recorded. Voucher specimens were brought to the Ethiopian Biodiversity Institute for identification and deposited there. $R$ program version 12.5.2 software and Microsoft Excel spreadsheet were used to analyze plant community classification and structural analysis, respectively. A total of 76 woody species representing 40 families were recorded. Rubiaceae was the dominant family followed by Asteraceae. The average Shannon-Wiener diversity index $\left(H^{\prime}\right)$ and the average evenness values of Wurg forest were 3.38 and 0.90 , respectively. Four plant community types were identified by using the presence/absence values of each species. The total density of woody species with $\mathrm{DBH}>2.5 \mathrm{~cm}$ was $1745.3 \mathrm{ha}^{-1}$. The DBH and height class distributions showed an inverted $J$-shaped pattern, which indicates a good regeneration potential of the forest. The most frequently observed species (92\%) was Syzygium guineense, which contributed $46 \%$ of the total basal area. The composition of seedling, sapling, and adult trees/shrubs species was $4966.07 \mathrm{ha}^{-1}, 3125.78 \mathrm{ha}^{-1}$, and $1745.27 \mathrm{ha}^{-1}$, respectively. However, the major threat to the forest was selective cutting of some woody species for various purposes. Therefore, raising local community awareness on conservation and sustainable use of the forest and exploring various alternatives for local communities' livelihood and promoting private and community plantations are recommendable.
\end{abstract}

\section{Introduction}

1.1. Background and Justification. Ethiopia has great geographic and biocultural diversities and agroclimatic variability, which endowed the country with prodigious diversity of biological resources. These made Ethiopia one of biodiversity rich countries in the world hosting the eastern Afromontane and the horn of Africa hotspots [1]. Its vegetation diversity ranges from high altitude Afroalpine in the central highlands to arid lowlands in the east and the rain forests in the west [2], which also harbor rare and endangered species and high amounts of endemism in floral diversities. Evidences showed that Ethiopia owns the fifth largest floral composition in tropical Africa [3]. The flora of
Ethiopia comprises 6,027 vascular plant species, of which $10 \%$ are endemic [4].

Ethiopia was rich in natural forests. Historical sources indicate that on the basis of potential climatic climax, high forests have once covered about $35-40 \%$ of the total land area of the country [5]. These habitats have dramatically declined in size and quality in the last century. By the beginning of the early 1950s, high forest areas were reduced to $16 \%$ of the total land area; by the early 1980s, the land area covered by the forest had dropped to about $3.96 \%$, and it was finally reduced to about $2.36 \%$ in 2000 [6]. However, the forest cover has showed a leap jump to $11 \%$ following new definition of forest that includes woodland forests besides natural forests. Ethiopia has 12.3 million hectares of forests 
comprising of natural and planted forests, wooded land with coverage of about $15 \%$ of the country, of which planted forests constitute about $8 \%$ [1]. Currently, Ethiopia has about 17.35 million hectares of forests $(15.7 \%$ of the country's area), which include bamboo, dense woodland, natural forests, and planted forests. This estimation includes a land spanning more than 0.5 hectare covered by trees attaining a height of $>2 \mathrm{~m}$ and a canopy cover of $>20 \%$ or trees with potential to reach these thresholds in situ in due course [7].

The declining of vegetation resources in all areas of the country in general and fragmented areas in forests in particular is mainly due to increased population growth followed by deforestation and land degradation [8]. The rapid increase of population in the country has resulted in extensive forest clearing for agricultural uses, resettlement schemes, exploitation of the existing forests for fuel wood, construction materials, and setting forest fire for pasture [9]. Researchers [10] also explained that tropical forest ecosystems are threatened because of relatively high population densities that have led to agricultural expansion and increased human dependence for fuelwood, nontimber forest products, and grazing of livestock. Most of the remaining forests of Ethiopia are confined to the south and southwestern parts of the country, which are less accessible and/or less populated $[11,12]$. Nowadays, even the remnant natural forests in these areas are continuously threatened by human activities [13].

Vegetation structure is the distribution of individuals of each species in order to determine the overall regeneration profile of the forest vegetation based on the tree/shrub density, frequency, height, $\mathrm{DBH}$, basal area, and important value index of the species [14]. Information on population structures of tree and shrub species indicates the history of past disturbance to the species and environment. It is also used to forecast the future trend of the particular species that could provide information for conservation and management strategies $[15,16]$.

Botanical assessments such as floristic composition, species diversity, and structural analysis provide information on species richness of the forest, useful for forest management purpose and help in understanding forest ecology and ecosystem function [17]. Several studies have been made on vegetations of Ethiopia on different areas, for instance, [18-22] have studied floristic composition and phytogeographical studies. Other workers [8,23-25] have considered floristic composition and diversity. $[12,26,27]$ have made studies on plant community and ecological studies. Floristic composition and vegetation structural studies were also conducted [14, 28-33]. Although some researchers [34] examined woody plant species diversity, population structure, and regeneration status, yet problems of forest decline remained unresolved in the country. The study area, Wurg forest, is one of the natural Afromontane forests containing useful but threatened tree/shrub species in Maji Woreda (district), southwestern Ethiopia. Although the forest provides material and nonmaterial benefits to the local community, awareness among local communities and efforts made on its sustainable use stayed inadequate. Moreover, there were no ecological works conducted in the area. Therefore, objectives of the current study were to assess woody plant species composition and diversity of Wurg forest, analyze vegetation structure, examine plant community types, and determine the regeneration status of woody plant species of the forest that could help to develop appropriate management plan to ensure biodiversity conservation and sustainable use so that the forest could also serve as a seed source for the restoration of degraded areas.

\section{Materials and Methods}

2.1. Description of the Study Area. The study area, Wurg forest of Maji Woreda, southwest Ethiopia (Figure 1), extends from $5^{\circ} 12^{\prime} 0^{\prime \prime}$ to $6^{\circ} 25^{\prime} 30^{\prime \prime}{ }^{\circ} \mathrm{N}$ latitude and $35^{\circ} 15^{\prime} 0^{\prime \prime}$ to $36^{\circ} 18^{\prime} 0^{\prime \prime} \mathrm{E}$ longitude. The capital city of the Woreda, Tum, is located $737 \mathrm{~km}$ southwest of Addis Ababa, the capital of Ethiopia. The study area is characterized by varied land features, including mountains, flatland, and agricultural fields. The altitude varies from $900 \mathrm{~m}$ to 2500 masl [35]. The study site, Wurg natural forest, belongs to Afromontane forest located about $34 \mathrm{~km}$ away from Tum with an altitude ranging from 1929 to 2500 masl.

Maji Woreda has 4 major traditional agroclimatic zones, 12\% Dega (highland), 42.8\% Woyna Dega (midhighland), $40.6 \%$ Kola (low land), and 4.6\% Bereha (desert and semidesert). Temperature and rain fall data were collected from the National Meteorological Agency (NMA). The mean annual temperature of the study area was $16.1^{\circ} \mathrm{C}$. The mean maximum and minimum temperatures recorded in March and November were $24.7^{\circ} \mathrm{C}$ and $7.9^{\circ} \mathrm{C}$, respectively (Figure 2).

The area receives mean annual rainfall of $1321.1 \mathrm{~mm}$ with a bimodal pattern, which falls much between March and May. Maji Woreda has a total population of 41,546 (19,985 males and 21,561 females). It covers a total area of about 691,160 ha (43\% cultivated land, $14.5 \%$ grazing land, $15.2 \%$ forest and shrub land, $1.8 \%$ uncultivable land, and $25.2 \%$ covered with other land use types) [36]. Nonetheless, the total area of Wurg forest was 2000 hectares.

The vegetation of the study area includes shrub lands, grasslands, scattered trees, range lands, and forests [37]. However [38], classified forests of the southwestern Ethiopia as lowland dry peripheral semi-evergreen Guineo-Congolian-type forest, transitional rain forest, broadleaved Afromontane rain forest, undifferentiated Afromontane forest, dry single Afromontane forest, and transition between dry single dominant Afromontane forest and east African evergreen and semi-evergreen bushland and tickets. Some characteristic plant species of the area include Allophylus abyssinicus, Nuxia congesta, Oxyanthus speciosus, Polyscias fulva, Syzygium guineense, Schefflera volkensii, and Vepris dainellii, whereas species of wildlife include impala, leopard, lion, the exceptional herds of eland, lesser kudu, elephant, giraffe, buffalo, waterbuck, hartebeest, oryx, Burchell's zebra, and the common baboon [39]. Yellow-billed kite, brown snake eagle, pied king fisher, and crested francolin are 


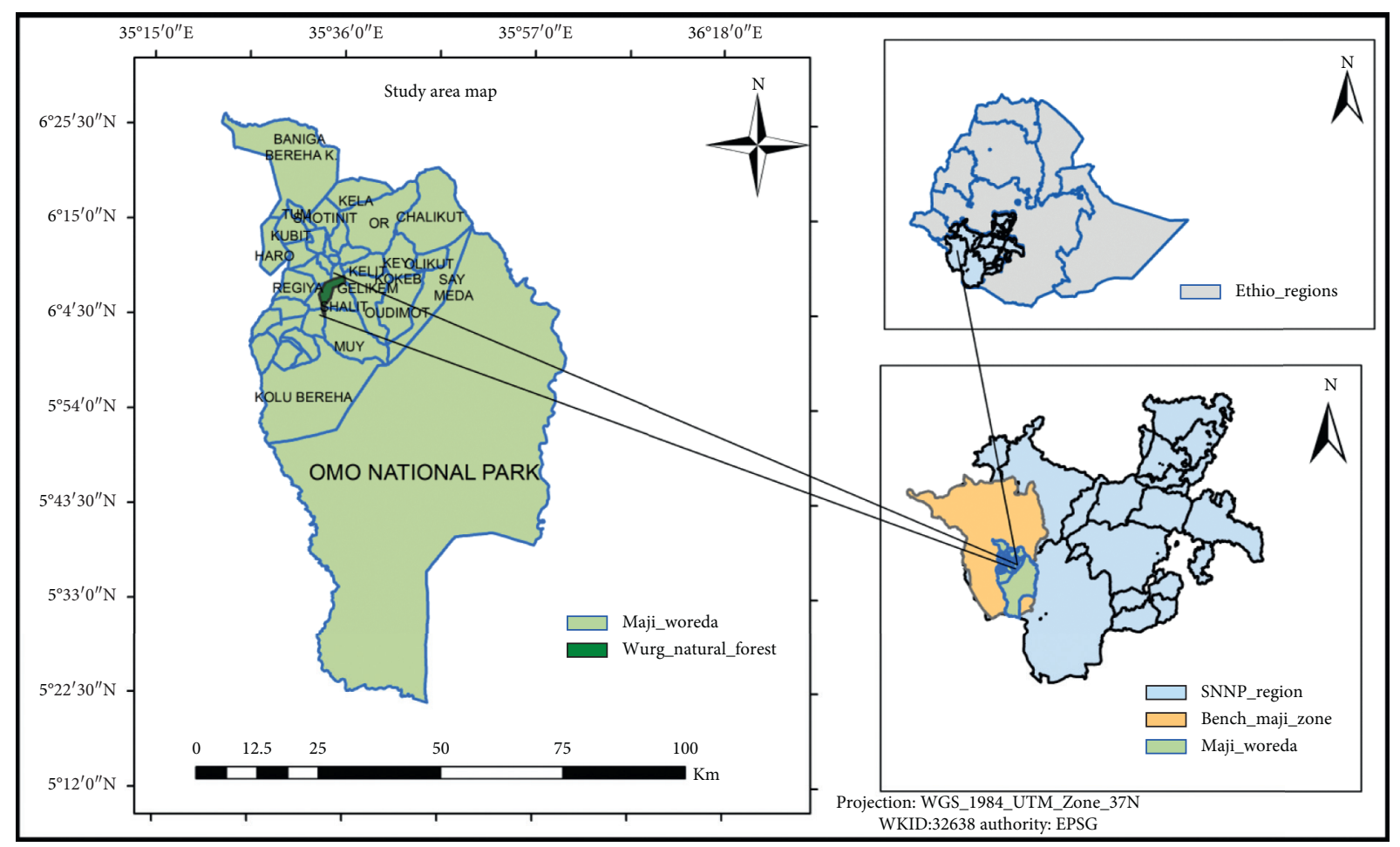

FIGURE 1: Location map of the study area.

some of the bird species in the area [40]. The soil of the Woreda is moderately acidic with the high cation exchange capacity classified as Nitosols, Regosols, and Acrisols [41].

2.2. Reconnaissance Survey and Sampling Design. Reconnaissance survey was made on 25-30 August 2017 in and around Wurg forest to obtain relevant information about the forest and to identify possible sampling sites. Systematic sampling was employed to collect vegetation data following [42]. The sampling sites were arranged in eight transect lines. Along each transect, eight $20 \mathrm{~m} \times 20 \mathrm{~m}\left(400 \mathrm{~m}^{2}\right)$ samples for trees and shrubs and $51 \mathrm{~m} \times 1 \mathrm{~m}$ area in each main plot for saplings and seedlings were laid to collect woody plant species data. Seedlings and saplings data of the woody plant species were collected to determine regeneration status of the forest. Distance between the main plots was $200 \mathrm{~m}$ and between the transect lines was $400 \mathrm{~m}$ apart. A total of 64 sample plots were laid for vegetation data collection.

Data were collected from 10 October to 15 December 2017. During vegetation data collection, physiographic variables such as altitude, slope, latitude, and longitude of each sample plot were recorded. Woody plant species in each plot was recorded using local names. Voucher specimens were collected, pressed, dried, and brought to the Ethiopian Biodiversity Institute for taxonomic identification, and the specimens were deposited there.

DBH of woody plant species $(\mathrm{DBH}>2.5 \mathrm{~cm})$ was measured at the height of $1.3 \mathrm{~m}$ using a tape meter. Height of all woody species in the sample plot (height $\geq 2 \mathrm{~m}$ ) was measured using a hypsometer for taller trees and shrubs and

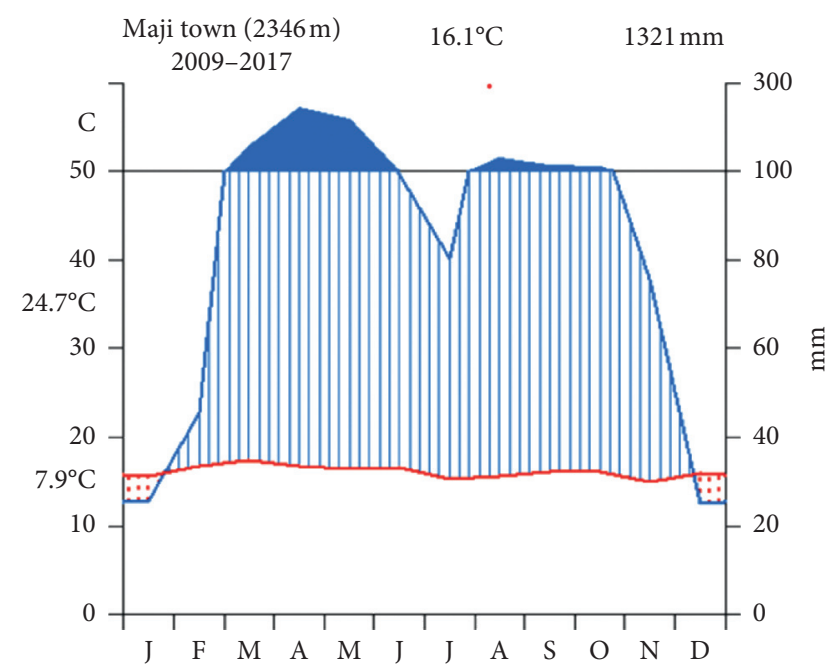

Figure 2: Climadiagram of Maji (the closest station).

calibrated pole marked at $0.5 \mathrm{~m}$ intervals and $4 \mathrm{~m}$ long, but visual estimates were used when the topography made difficult to measure. Woody plant species with $\mathrm{DBH}<2.5$ and height $<1 \mathrm{~m}$ were considered as seedling, and woody plants with height 1-2 $\mathrm{m}$ considered as sapling were counted only for vegetation composition following [43].

\subsection{Methods of Data Analysis}

2.3.1. Plant Community Analysis. The vegetation community analysis was made by the cluster analysis based on the 
species composition similarities of plots. Agglomerative hierarchical classification using similarity ratio cluster analysis was performed using $R$ software version 2.15.1 [44] to classify vegetation into plant community types based on the presence/absence value of species in each sample plot. The values were deployed only on the species abundance and frequency comparisons.

2.3.2. Diversity Indices. Biological diversity can be measured using different indices. The diversity indices of different community types were calculated using the Shannon-Wiener diversity index $\left(H^{\prime}\right)$ because it accounts both for species richness and evenness, and it is not affected by the sample size [45].

Shannon-Wiener diversity index and evenness were calculated using the following formula:

$$
H^{\prime}=-\sum_{i=1}^{s} p_{i} \ln p_{i}
$$

where $H^{\prime}$ is the Shannon diversity index; $S$ is the the number of species; $P_{i}$ is the proportion of individual species, and $\ln$ is the log base.

Evenness (equitability) is measured as the relative abundance of the different species making up the richness of an area and when compared the similarity of the population size of the species present.
Shannon equitability $(J)$ or evenness was calculated using

$$
J=\frac{H^{\prime}}{H_{\max }^{\prime}},
$$

$J$ is the evenness, $H^{\prime}$ is the Shannon-Wiener diversity index, and $H_{\max }^{\prime}=\ln S$, where $\ln$ is the natural logarithm, and $S$ is the total number of species in the sample.

2.3.3. Structural Analysis. Basal area (BA), density (D), frequency $(F)$, dominance (DO), and importance value index (IVI) data were calculated to describe woody species structure in the forest. Though the population structure of plants is described either by age, size, or life stage, the population structure of perennial woody species is often estimated by size class distribution [46]. The vegetation data were organized and analyzed by Microsoft Excel (2007) spreadsheet, and calculated using the formula developed by $[42,45]$.

Basal area (BA) was calculated as

$$
\mathrm{BA}=\frac{\pi d^{2}}{4},
$$

where $\mathrm{BA}$ is the basal area in square meter per hectare; $d$, is the diameter at breast height in meter; $\pi=3.14$.

$$
\begin{aligned}
\text { Dominance }(\mathrm{DO}) & =\frac{\text { basal area of species }}{\text { area of quadrates in hectare }}, \\
\text { Relative dominance }(\mathrm{RDO}) & =\frac{\text { dominance of species i }}{\text { the sum of dominance of all species }} \times 100 \%, \\
\text { Frequency }(\mathrm{F}) & =\frac{\text { number of plots in which species i occur }}{\text { total number plots laid down in the study site }} 100 \%, \\
\text { Relative frequency }(\mathrm{Rf}) & =\frac{\text { frequency of species i }}{\text { the sum of frequency of all species }} \times 100 \%, \\
\text { Density } & =\frac{\text { total number of all trees }}{\text { sample size in hectare }} \times 100, \\
\text { Relative density }(\mathrm{RD}) & =\frac{\text { density of species i }}{\text { the sum of density of all species }} \times 100 \% .
\end{aligned}
$$

Importance value index is the sum of the relative basal area (BA), relative frequency (RF), and relative density (RD).

$$
\text { Important value index }(\mathrm{IVI})=\mathrm{RDO}+\mathrm{RF}+\mathrm{RD} \text {. }
$$

2.4. Regeneration Status of the Forest. It was studied to enhance future conservation priority of the forest. The regeneration status of species was determined based on the population size of seedlings and saplings [47] as good regeneration if seedlings $>$ saplings $>$ adults and fair regeneration if seedlings $>$ or $\leq$ saplings $\leq$ adults. Nonetheless, the regeneration status was considered as poor if the species is represented by only saplings (saplings $\leq$ or $\geq$ adults) and as not regenerating when a species is represented by only trees.

For this study, woody plant species with $\mathrm{DBH}<2.5 \mathrm{~cm}$ and height $<1 \mathrm{~m}$ were considered as seedlings, woody plants with height 1-2 $\mathrm{m}$ were considered as sapling, and seedlings 
or woody plants with height $>2$ were considered as trees/ shrubs [43].

2.5. Analysis of Vertical Structure. The vertical structure of trees in Wurg forest was examined using the International Union of Forest Research Organizations (IUFRO) classification scheme [48]. According to IUFRO classification scheme, three vertical structures were distinguished in tropical forests, namely, the upper story (tree height $>2 / 3$ of top height), middle story (tree height between $1 / 3$ and $2 / 3$ of top height), and the lower story $(<1 / 3$ of the top height).

\section{Result and Discussion}

3.1. Woody Species Composition. Seventy six woody species (Table 1) belonging to 64 genera and 40 families were identified from Wurg forest. Out of these, 35 (46.1\%), 32 $(42.1 \%)$, and $9(11.8 \%)$ were trees, shrubs, and lianas, respectively (Figure 3 ). This study indicated large number of trees species than other plant habits in contrast to previous studies performed by [24, 25, 49] who have reported small number of tree habit in their respective study areas. Likewise, the number of woody species composition of Wurg forest is higher than woody species composition of other forests in Ethiopia including Wotagisho forest (51 species) [25], Lammo natural forest (54 species) [32], Guraferda forest (66 species) [49], and Tara Gedam forest (41 species) [50] showing that Wurg forest has relatively large number of forest plant species, which signals the significance of enhancing various forest conservation efforts. One study [26] discussed that forests in southwestern Ethiopia are rich in species composition, and the richness tends to decrease as one goes to the north. However, the number of woody species composition of Wurg forest is smaller than Komatsu Moist Afromontane forest (103 species) [29], moist evergreen montane forest (106 species) [51], and Boda dry evergreen forest (95 species) [24].

However, out of the identified woody species, Wurg forest sheltered relatively few number of endemic plant species to Ethiopia [52], namely, Dombeya longebracteolata, Millettia ferruginea, Vepris dainellii, and Vernonia leopoldi.

3.2. Plant Community Classification. Four plant community types were identified from the cluster analysis (Figure 4) based on group of plots that were similar in their species composition. The indicator value of each species in each group and a test for statistical significance $(p<0.05)$ were analyzed to give plant community types (Tables 2 and 3 ).

(1) Pavetta abyssinica-Oxyanthus speciosus community, which was situated at an altitudinal range of 1950_2364 m.asl, contained 20 plots and 58 species. The indicator species in the community were Pavetta abyssinica and Oxyanthus speciosus. The dominant species in the tree layer were Elaedendron buchananii, Syzygium guineense, and Ficus sur, but Calpurnia aurea, Maytenus arbutifolia, Maytenus senegalensis, and Galiniera saxifraga were associated in the shrub layer. Embelia schimperi was the dominant liana in this community.

(2) Periploca linearifolia-Rhamnus prinoides community was located at an altitudinal range of 1929-2172 m, which consisted of 5 plots and 35 species. The tree species in the upper canopy of the community were Elaedendron buchananii, Macaranga capensis, Syzygium guineense, and Bridelia micrantha. The shrub layers include Maytenus arbutifolia, Psydrax parviflora, and Premna schimperi. However, Dioscorea Shimperiana was a common liana of the community.

(3) Psydrax parviflora-Allophylus abyssinica community was situated at an altitudinal range of 2033-2279 m.asl that contained 20 plots and 41 species. Syzygium guineense was the dominant tree in the upper canopy layer. The shrub layer includes Maytenus arbutifolia, Oxyanthus speciosus, and Pavetta abyssinica.

(4) Maytenus arbutifolia-Maesa lanceolata community was found at an altitudinal range $2182-2501 \mathrm{~m} \cdot$ asl containing 19 plots and 42species. Macaranga capensis and Syzygium guineense were the tree species in the canopy layer. Bersama abyssinica, Maytenus senegalensis, Oxyanthus speciosus, and Maesa lanceolata were species situated in the shrub layer.

3.3. Species Diversity, Richness, and Evenness of the Plant Community Types. It is obvious that plant community features such as species richness, evenness, and composition could vary along altitudinal gradients. In the current study area, plant community type I has the highest number of species (species richness) and species diversity $\left(H^{\prime}\right)$ with fairly even distribution (Table 4). Community II has the smallest species richness but with highest species evenness. In general, except community II, all the community types have similar species evenness. The overall average Shannon-Wiener diversity index $\left(H^{\prime}\right)$ and the average evenness values of Wurg forest were 3.38 and 0.90 , respectively, which is higher than Harenna forest [41] and Yemrehane Krestos Church forest of northern Ethiopia [53], which had 2.88 and 0.79 values, respectively.

According to [41], when there is a high evenness value in a forest, the location of the conservation site might not be important as compared to the forest with a low evenness value. However, according to [54], $H^{\prime}$ values usually fall between 1.5 and 3.5, and its value is high when the relative abundance of the different species in the sample is even. Accordingly, plant community types of the study forest had relatively higher $H^{\prime}$ and evenness value. It was discussed that the variation in species richness and diversity of the plant community could be attributed to variation in altitude, disturbance, and other factors, but the variation in the environmental factors of the study area seems to be insignificant [41].

3.4. Vegetation Structure. The total density of woody species with $\mathrm{DBH}>2.5 \mathrm{~cm}$ in Wurg forest was $1745.27 \mathrm{ha}^{-1}$. One study [55] reported 3328.47 individuals $\mathrm{ha}^{-1}$ as the total 
TABLE 1: List of Woody species collected and identified from Wurg forest, southern Ethiopia.

\begin{tabular}{|c|c|c|c|c|}
\hline No & Scientific name & Family & Local name & Habit \\
\hline 1 & Albizia schimperiana Olive., C. Sm. & Fabaceae & Ziinu & Tree \\
\hline 2 & Allophylus abyssinicus (Hochst.) Radlkofer. & Sapindaceae & Xhiyashi & Tree \\
\hline 3 & Asparagus africanus Lam. & Asparagaceae & Uutn gorkn & Liana \\
\hline 4 & Bersama abyssinica Fresen. & Melianthaceae & Zokuknaabuchuo & Tree \\
\hline 5 & Bridelia micrantha (Hochst.) Robyns. & Euphorbiaceae & Echim & Tree \\
\hline 6 & Brucea antidysentrica J. F. Mill. & Simaroubaceae & Diyagn & Tree \\
\hline 7 & Buddleja polystachya Fresen. & Loganiaceae & Dekn & Shrub \\
\hline 8 & Calpurnia aurea (Ait.) & Fabaceae & Hirshun & Shrub \\
\hline 9 & Canthium oligocarpum Hiern. & Rubiaceae & Xhalbizh & Shrub \\
\hline 10 & Capparis micrantha A. Rich. & Capparidaceae & Zelm & Shrub \\
\hline 11 & Carissa spinarum L. & Apocynaceae & Niyadin & Shrub \\
\hline 12 & Clausena anisata (Wild.) Hook. F. ex. Benth & Rutaceae & Uwilaushim & Shrub \\
\hline 13 & Clerodendrum myricoides (Hochst.) Vatke. & Lamiaceae & Mulmuuzu & Shrub \\
\hline 14 & Clutia abyssinica Jaub. \& Spach & Euphorbiaceae & Tiartiar & Shrub \\
\hline 15 & Coffea arabica $\mathrm{L}$. & Rubiaceae & Giyanu & Shrub \\
\hline 16 & Cordia africana Lam. & Boraginaceae & Abshi & Tree \\
\hline 17 & Dalbergia lactea Vatke & Fabaceae & Raadi & Liana \\
\hline 18 & Dioscorea shimperiana Hochst. ex Kunth. & Dioscoreaceae & Yagd & Liana \\
\hline 19 & Diospyros abyssinica (Hiern.) F. White & Ebenaceae & Tsuolu & Tree \\
\hline 20 & Dombeya longebracteolata Seyani & Sterculiaceae & Shubshu & Shrub \\
\hline 21 & Dombeya torrida (J. F. Gummel.) P. Bamps & Sterculiaceae & Buoshn & Tree \\
\hline 22 & Dracaena fragrans (L.) Ker Gawl & Dracenaceae & Guoru & Shrub \\
\hline 23 & Dracaena steudneri Engler. & Dracenaceae & Uwezi & Tree \\
\hline 24 & Ekebergia capensis Sparm. & Meliaceae & Xsuwi & Tree \\
\hline 25 & Elaedendron buchananii (Loes) Loes. & Celastraceae & Gorshin & Tree \\
\hline 26 & Embelia schimperi Vatke & Myrsinaceae & Meding & Liana \\
\hline 27 & Ehretia cymosa Thonn. & Boraginaceae & Kuumu & Tree \\
\hline 28 & Euphorbia ampliphylla Pax. & Euphorbiaceae & Dangar & Tree \\
\hline 29 & Ficus sur Forssk. & Moraceae & Chiyamu & Tree \\
\hline 30 & Galiniera saxifraga (Hochst.) Bridson & Rubiaceae & Burntsubuz & Tree \\
\hline 31 & Grewia ferruginea Hochst. ex. A. Rich & Tiliaceae & Xhabxhab & Shrub \\
\hline 32 & Hypericum revolutum Vahl. & Hypericaceae & Yarmqushin & Shrub \\
\hline 33 & Jasminum dichotomum Vahl. & Oleaceae & Ietsu & Liana \\
\hline 34 & Keetia gueinzii (Sond.) Bridson. & Rubiaceae & Xustnkaykiz & Liana \\
\hline 35 & Macaranga capensis (Ball) Sim. & Euphorbiaceae & Chanm & Tree \\
\hline 36 & Maesa lanceolata Forssk. & Myrsinaceae & Tulu & Shrub \\
\hline 37 & Maytenus senegalensis (Lam.) & Celastraceae & Tsutsu & Shrub \\
\hline 38 & Maytenus arbutifolia (A. Rich) Wilczek & Celastraceae & Shishir & Shrub \\
\hline 39 & Millettia ferruginea (Hochst) Balk & Fabaceae & Ziyagi (Birbir) & Tree \\
\hline 40 & Myrsine africana $\mathrm{L}$. & Myrsinaceae & Shugiti & Shrub \\
\hline 41 & Nuxia congesta R. Br. ex Fresen. & Loganiaceae & Ebsu & Tree \\
\hline 42 & Ocimum lamiifolium Hochst. ex Benth. & Lamiaceae & Michiziibu & Shrub \\
\hline 43 & Olea europea subsp. cuspidata (Wall. ex. Dc) Cifferri. & Oleaceae & Orsu & Tree \\
\hline 44 & Olea welwitschii (Knobl.) Gilg \& Schellenb. & Oleaceae & Qiyagu & Tree \\
\hline 45 & Olinia rochetiana A. Juss. & Oliniaceae & Gundu & Tree \\
\hline 46 & Osyris quadripartita Dec. & Santalaceae & Goym & Tree \\
\hline 47 & Ocotea kenyensis (Chiov.) Robyns \& Wilcz. & Lauraceae & Diemu & Tree \\
\hline 48 & Oxyanthus speciosus DC. & Rubiaceae & Tsirbu & Shrub \\
\hline 49 & Ozora insignis Del. & Anacardiaceae & Gaaznguonu & Tree \\
\hline 50 & Pavetta abyssinica Fresen. & Rubiaceae & Nebdi & Shrub \\
\hline 51 & Pavetta oliveriana Hiern. & Rubiaceae & Burngeydnz & Shrub \\
\hline 52 & Periploca linearifolia Quart. Dill. \& A. rich & Asclepiadaceae & Dabu & Liana \\
\hline 53 & Phoenix reclinata Jacq. & Arecaceae & Engi & Tree \\
\hline 54 & Phytolacca dodecandra L. Herit & Phytolaccaceae & Sholshin & Shrub \\
\hline 55 & Pittosporum viridiflorum Sims & Pittosporaceae & Botkuxhiali & Tree \\
\hline 56 & Polyscias fulva (Hiern) Harms & Araliaceae & Kajul & Tree \\
\hline 57 & Premna schimperi Engl. & Verbanaceae & Xiads & Shrub \\
\hline 58 & Prunus africana (Hook. f.) Kalkm. & Rosaceae & Okum & Tree \\
\hline 59 & Psydrax parviflora (Afz.) Bridson & Rubiaceae & Giyan uinchi & Tree \\
\hline 60 & Rhamnus prinoides L. Herit & Rhamnaceae & Belbonku & Shrub \\
\hline
\end{tabular}


TABle 1: Continued.

\begin{tabular}{|c|c|c|c|c|}
\hline No & Scientific name & Family & Local name & Habit \\
\hline 61 & Rhamnus staddo A. Rich & Rhamnaceae & Temdi & Shrub \\
\hline 62 & Rhoicissius tridentata (L. f.) Wild \& Drummud & Vitaceae & Bonture & Liana \\
\hline 63 & Rhus glutinosa A. Rich & Anacardiaceae & Chiyapm & Shrub \\
\hline 64 & Rhus vulgaris Meikle & Anacardiaceae & Guutin & Shrub \\
\hline 65 & Rubus apetalus Poir. & Rosaceae & Gorknaguochi & Shrub \\
\hline 66 & Sapium ellipticum (Krauss) Pax & Euphorbiaceae & Balu & Tree \\
\hline 67 & Schefflera abyssinica (Hochst. ex. A. Rich.) Harms & Araliaceae & Kuoru & Tree \\
\hline 68 & Schefflera volkensii (Harms) Harms & Araliaceae & Chomuz & Tree \\
\hline 69 & Syzygium guineense (Wild.) DC. & Myrtaceae & Chuoru & Tree \\
\hline 70 & Urera hyselodendron (A. Rich.) Wedd. & Urticaceae & Shotn & Liana \\
\hline 71 & Vepris dainellii (Pich. Serm.) Kokwaro & Rutaceae & Totib & Tree \\
\hline 72 & Vernonia amygdalina Del. & Asteraceae & Kwikn & Shrub \\
\hline 73 & Vernonia auriculifera Hiern & Asteraceae & Gaaru & Shrub \\
\hline 74 & Vernonia bipotini Vatke & Asteraceae & Tsodgu & Shrub \\
\hline 75 & Vernonia leopoldi (Sch. Bip. ex Walp.) & Asteraceae & Dolgu & Shrub \\
\hline 76 & Vernonia myriantha Hook. f. & Asteraceae & Duogu & Shrub \\
\hline
\end{tabular}
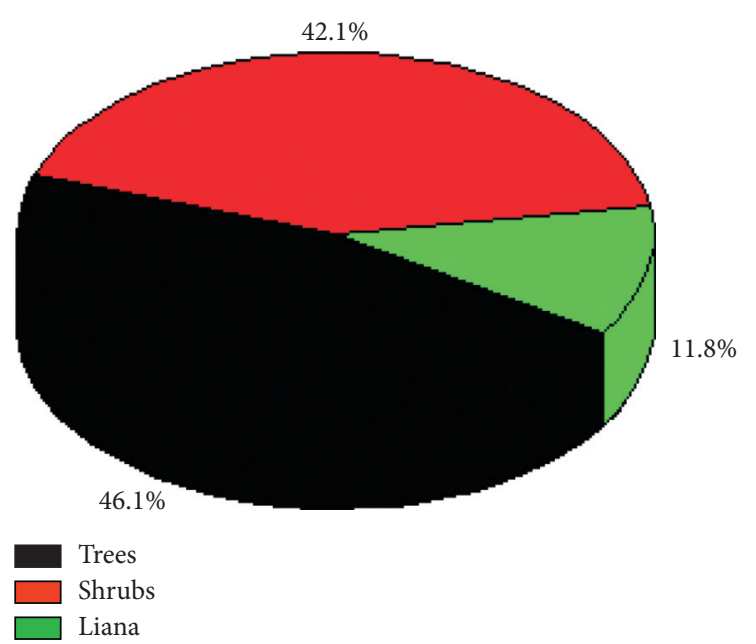

Figure 3: Percentage of plant habit of Wurg forest.

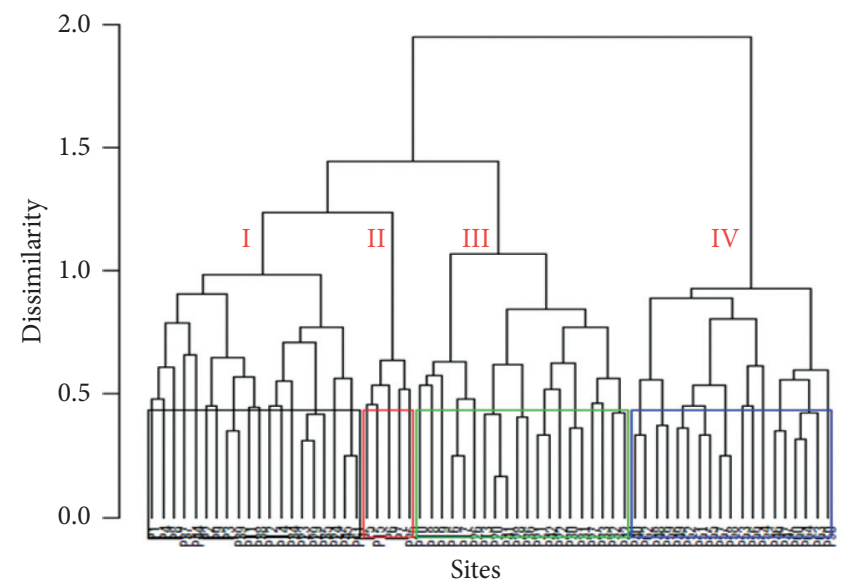

Figure 4: Dendrogram showing the plant community types of Wurg forest.

density of woody plant species from central highland of Chilimo-Gaji forest of Ethiopia. This variation could be attributed to the quantity and intensity of disturbances in the area. Species with the highest density in the study area were Psydrax parviflora and Oxyanthus speciosus with $372.27 \mathrm{ha}^{-1}$ (21\%) and $285 \mathrm{ha}^{-1}(16 \%)$, respectively. Maytenus arbutifolia was represented by density $117.97 \mathrm{ha}^{-1}(6.76)$, and other species were represented by density $<5 \%$. The least dense species were Diospyros abyssinica, Jasminum dichotomum, Rhus glutinosa, Dracaena steudneri, Capparis micrantha, and Ocimum lamiifolium with only a single individual per hectare, which indicates the need of thoughtful attention towards the conservation of these species.

The ratio of the density of trees/shrubs with $10 \mathrm{~cm}<\mathrm{DBH}<20 \mathrm{~cm}$ and $>20 \mathrm{~cm}$ was taken as a measure of class size distribution [56]. Accordingly, the value of this ratio was 2.35. This indicates the predominance of smallsized individuals in Wurg forest. The ratio of the density of trees/shrubs with $10 \mathrm{~cm}<\mathrm{DBH}<20 \mathrm{~cm}$ and $>20 \mathrm{~cm} \mathrm{DBH}$ was also compared to the nine other Afromontane forests studied in Ethiopia (Table 5).

When compared to the other Afromontane forests of Ethiopia, the ratio of the density of individuals with $\mathrm{DBH}>10 \mathrm{~cm}$ to density $>20 \mathrm{~cm} \mathrm{DBH}$, Wurg forest was much greater than other forests except Masha forest. This indicates that Wurg forest has greater individuals with smaller DBH classes (Table 5) where forest regeneration in particular and the predictability of the forest sustainability seem to be relatively higher. On the other hand, the ratio of density of individuals with $\mathrm{DBH}>10 \mathrm{~cm}$ to density $>20 \mathrm{~cm}$ $\mathrm{DBH}$, Wurg forest is more or less similar to Masha [20]. This similarity may be associated with geographical location, climatic condition, altitude, or other disturbance factors where the two forests are geographically located to the southwestern part of the country.

3.5. DBH Class Distribution. The DBH class distribution of woody plant species of Wurg forest was classified into nine classes, and the density of individuals of the different $\mathrm{DBH}$ classes is given in Figure 5. The overall density distribution of individuals in the forest decreased from lower DBH classes to higher $\mathrm{DBH}$ classes. The lowest $\mathrm{DBH}$ class 1 with large 
TABLE 2: Indicator species for each community type and the test significant ${ }^{* *} p$ value observed.

\begin{tabular}{lccccc}
\hline Community type & CI & CII & CIII & CIV & $p$ value \\
\hline Pavetta abyssinica & 0.95 & 1 & 0.9 & 0.42 & 0.017 \\
Oxyanthus speciosus & 0.85 & 0 & 0.85 & 0.026 \\
Periploca linearifolia & 0.4 & 1 & 0 & 0.05 & 0.001 \\
Rhamnus prinoides & 0.45 & 1 & 0 & 0.37 & 0.003 \\
Psydrax parviflora & 0.65 & 0.6 & 0.85 & 0.11 & 0.001 \\
Allophylus abyssinica & 0.6 & 0.4 & 0.5 & 0.001 \\
Maytenus arbutifolia & 0.8 & 0.6 & 0.15 & 0.84 & 0.032 \\
Maesa lanceolata & 0.45 & & 1 & & 0.04 \\
\hline
\end{tabular}

${ }^{* *} p$ level of significance at $\infty=0.05$.

TABLE 3: The community types and distribution of sample plots.

\begin{tabular}{lcc}
\hline Community & No. of plots & Plots in the community \\
\hline CI & 20 & $1,2,3,4,8,9,12,14,23,24,29,34,35,37,38,39,44,45$, and 61 \\
CII & 5 & $5,6,7,15$, and 25 \\
CII & 20 & $10,13,16,17,18,19,20,21,22,26,27,28,30,31,32,33,36,41,42$, and 43 \\
CIV & 19 & $40,46,47,48,49,50,51,52,53,54,55,56,57,58,60,59,62,63$, and 64 \\
\hline
\end{tabular}

TABle 4: Shannon-Weiner diversity, species richness, and species evenness of the plant community.

\begin{tabular}{lcccc}
\hline Community types & Species richness & $H_{\max }$ & Species evenness $(J)$ & Diversity index $(\mathrm{H})$ \\
\hline CI & 58 & 4.06 & 0.88 & 3.59 \\
CII & 35 & 3.56 & 0.96 & 3.40 \\
CIII & 41 & 3.71 & 0.86 & 3.18 \\
CIV & 42 & 3.74 & 0.89 & 3.34 \\
Average values & & 3.77 & 0.90 & 3.38 \\
\hline
\end{tabular}

number of individuals constituted almost $60 \%$ of DBH class showing active regeneration. DBH classes in Wurg forest formed an inverted $J$-shaped structure, which indicates the predominance of smaller-sized individuals. This in turn shows a good regeneration and recruitment potential as reported by other studies $[62,63]$. Similar results were also reported from different Afromontane vegetations of Ethiopia [30, 31, 33, 59, 64, 65]. The predominance of smallsized individuals of the forest also shows that bigger trees were possibly removed for various purposes [23, 59].

3.6. Height Class Distribution. Height can be used as an indicator of the age of the forest. The height of trees and shrubs in the study area was conventionally classified into seven classes. The density of individuals in the different height classes decreased with increasing height classes. The highest density of individuals was observed in the height class 1 and the least density was observed in the height class 7. Generally, the density distribution of individuals in the different height classes was the same as the DBH class frequency distribution (Figure 5), i.e., inverted $J$ shape, which shows that the forest is in a good reproduction and regeneration potential (Figure 6). Similar results were reported by $[28,65,66]$.

3.7. Frequency. Frequency is the measure of the occurrence of a given species in a given area which indicates how species are dispersed and is ecologically a meaningful parameter
$[42,45]$. Smaller frequency may suggest clumped distribution of species, and higher frequency indicates a wide distribution of species. The number of frequency classes indicates homogeneity in forest composition [53]. The most frequently observed species in the current study area was Syzygium guineense, which occurred in 59 quadrates out of the 64 with a frequency of $92 \%$, which was followed by Maytenus arbutifolia (91\%) and Elaedendron buchananii (83\%) (Table 6). In Ethiopia, Syzygium guineense does very well in moist and wet Kolla and Woyna Dega agroclimatic zones of all regions at an altitude of 1200-2600 m, and the study area is also within this range where this species has flourished [67].

3.8. Basal Area. It is agreeable that the basal area offers the measure of the relative importance of the species. The total basal area of trees/shrubs in Wurg forest calculated from $\mathrm{DBH}$ was $126.47 \mathrm{~m}^{2} /$ ha. The total basal area reported for Chilimo-Gaji dry Afromontane forest was $454.52 \mathrm{~m}^{2} \cdot \mathrm{ha}^{-1}$ [55], which is much more than the current study. One study [68] reported $47,54,49,53$, and $46 \mathrm{~m}^{2} /$ ha basal area of woody species from Bonga, Berhane-Kontir, Harenna, Maji, and Yayu Afromontane forests of Ethiopia, respectively, which is more than twice less number than the Wurg forest. On the other hand, researchers [53] reported $72 \mathrm{~m}^{2} /$ ha basal area of the Church forest from northern Ethiopia, and the variation could be related with climate conditions where the diversity and luxury growth condition (density) in 
TABLE 5: Comparison of tree densities with DBH between 10 and 20, and $>20 \mathrm{~cm}$ from Wurg forest with other Afromontane forests of Ethiopia.

\begin{tabular}{|c|c|c|c|c|}
\hline Forest & $10 \mathrm{~cm}<\mathrm{DBH}<20 \mathrm{~cm}(a)$ & $>20 \mathrm{~cm} \mathrm{DBH}(b)$ & Ratio, $a / b$ & Forest type \\
\hline Masha $^{1}$ & 385.7 & 160.5 & 2.40 & Moist Afromontane \\
\hline Wurg $^{2}$ & 516.02 & 219.92 & 2.35 & Present study \\
\hline Menna Angetu ${ }^{3}$ & 292.59 & 139.78 & 2.09 & Moist Afromontane \\
\hline Belete $^{4}$ & 305.07 & 149 & 2.04 & Moist Afromontane \\
\hline Jima $^{5}$ & 335 & 184 & 1.80 & Moist Afromontane \\
\hline Magada $^{6}$ & 608 & 332 & 1.80 & Dry Afromontane \\
\hline Gedo $^{7}$ & 832 & 464 & 1.79 & Dry Afromontane \\
\hline Berbere $^{8}$ & 216.58 & 138.62 & 1.56 & Moist Afromontane \\
\hline Gelesha $^{9}$ & 315.42 & 244.52 & 1.29 & Moist Afromontane \\
\hline Guraferda ${ }^{10}$ & 633 & 499 & 1.27 & Moist Afromontane \\
\hline
\end{tabular}

Source: ${ }^{1}[20],{ }^{3}[57],{ }^{4}[30],{ }^{5}[58],{ }^{6}[59],{ }^{7}[60],{ }^{8}[33],{ }^{9}[61]$, and ${ }^{10}[49]$.

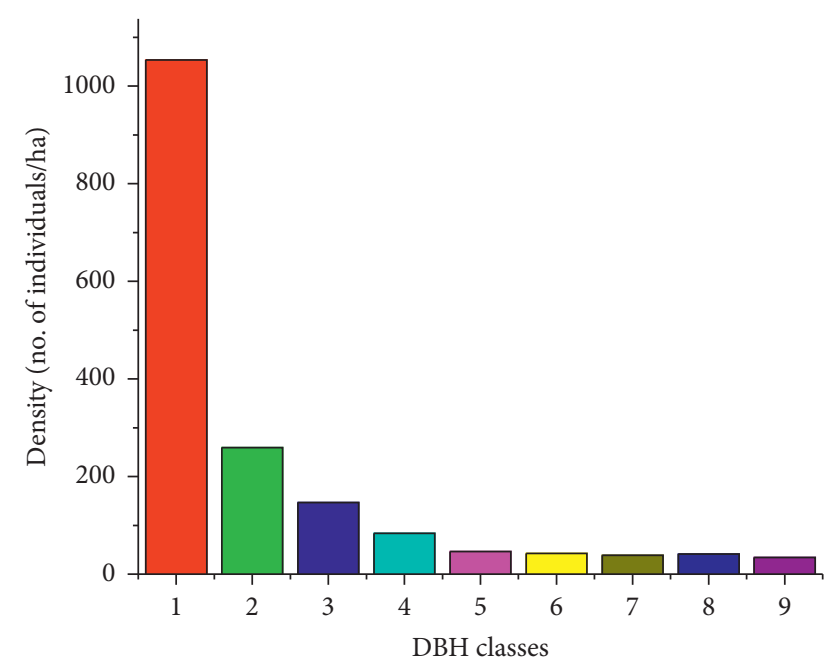

FIGURE 5: Density of individuals of woody plants in different DBH classes.

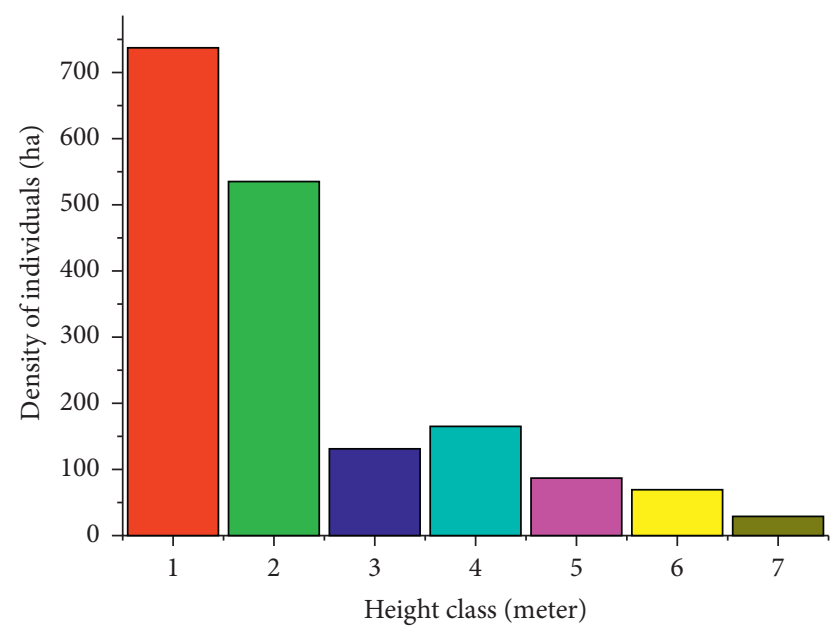

FIGURE 6: Density of individual woody plants in different height distributions of the forest. Height class 1 ranges from 2.1 to $6 \mathrm{~m} ; 2$ $(6.1-10 \mathrm{~m}) ; 3$ (10.1-14 m); 4 (14.1-18 m); 5 (18.1-22 m); 6 $(22.1-26 \mathrm{~m})$; and 7 (>26 m).
TABLE 6: Frequency distribution of some tree/shrub species of Wurg forest.

\begin{tabular}{lcccc}
\hline No & Species & $\begin{array}{c}\text { Number } \\
\text { of plots }\end{array}$ & Frequency & $\begin{array}{c}\text { Relative } \\
\text { frequency }\end{array}$ \\
\hline 1 & Syzygium guineense & 59 & 92.18 & 6.84 \\
2 & Maytenus arbutifolia & 58 & 90.63 & 6.72 \\
3 & Elaedendron & 53 & 82.81 & 6.15 \\
4 & buchananii & & 79.69 & 5.92 \\
5 & Oxyanthus speciosus & 51 & 76.56 & 5.69 \\
6 & Macaranga capensis & 49 & 76.56 & 5.69 \\
7 & Pavetta abyssinica & 49 & 71.88 & 5.34 \\
8 & Maytenus senegalensis & 46 & 67.17 & 4.99 \\
9 & Galiniera saxifraga & 43 & 65.62 & 4.87 \\
10 & Bersama abysinica & 42 & 56.25 & 4.18 \\
\hline
\end{tabular}

southwestern part is greater than northern part in the country. The higher basal area of the study forest than other related Afromontane forests of Ethiopia could be associated with a high density of individuals in the forest. Syzygium guineense has the largest basal area with $58.67 \mathrm{~m}^{2} /$ ha (46.39\%), which was followed by Macaranga capensis 15.97 (12.63) and Elaedendron buchananii 13.48 (10.66). Thus, the three tree species constituted $70 \%$ of the total basal area of the forest. Therefore, these tree species are considered as dominant species of the forest. In the current study forest, the first DBH class $(2.5-12.5 \mathrm{~cm})$ constituted about $48 \%$ of the total DBH classes but [66] reported that $46 \%$ in Yayu forest were found in the DBH class between 2 and $5 \mathrm{~cm}$. This also depicts us a good regeneration capacity of the two forests.

According to [69], dominant tree species is either a single or group of tree species accounting for more than $50 \%$ of basal area in the forest. The comparison of basal area to the different DBH classes shows that there is a considerable increase in basal area from lower $\mathrm{DBH}$ classes to higher $\mathrm{DBH}$ classes (Figure 7). Trees/shrubs in the highest DBH class contributed $31.31 \%$ of the total basal area in the forest. Basal area is a vital forest measurement, which can be used to evaluate forest resource. 


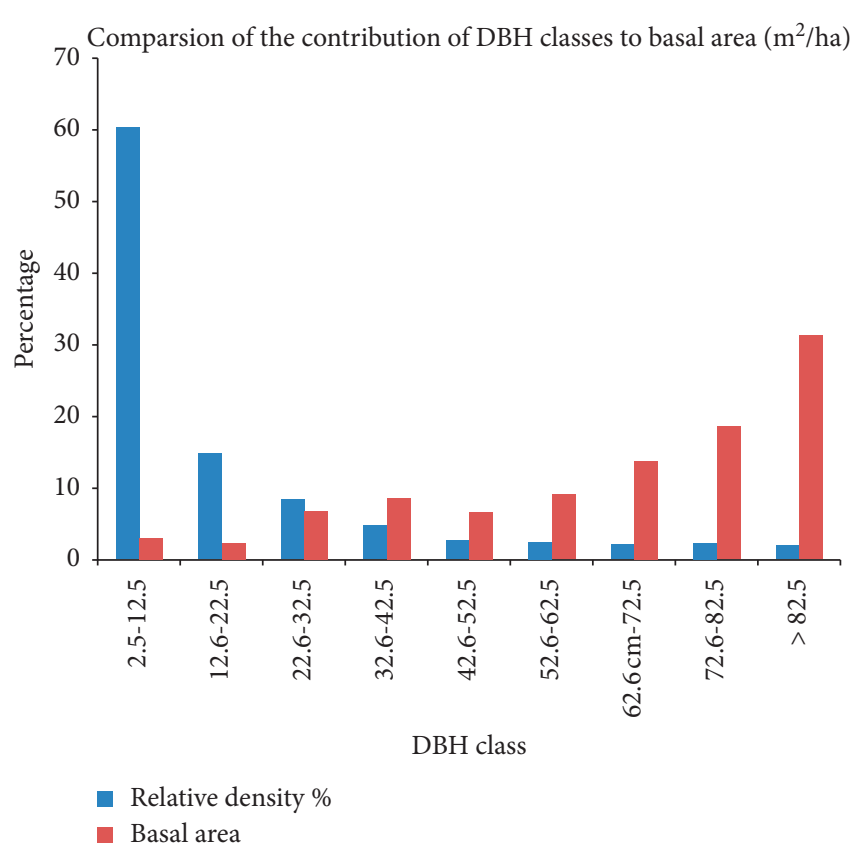

Figure 7: Comparison of the basal area with the different DBH classes of Wurg forest.

Basal area offers an improved measure of the relative importance of species than simple stem count. Thus, species with the largest basal area can be regarded as a vital species or dominant if a single or group of tree species accounting for more than $50 \%$ of the basal area in the study area. Accordingly, in the current study, Syzygium guineense followed by Macaranga capensis and Elaedendron buchananii have higher basal area and are taken as dominant species of Wurg forest. Previous workers [24] discussed Juniperus procera as the species with the largest basal area in Boda forest from central Ethiopia, and similarly, Albizia gummifera was reported from Yegof forest [34]. The basal area of Wurg forest was compared to ten other Afromontane forests of Ethiopia (Table 7). The basal area of Wurg forest is the third top higher from the compared ten forests in the country. Larger basal area of Wurg forest could be mainly associated with the presence of some old aged trees, which also indicate relatively little disturbance of the forest.

3.9. Importance Value Index (IVI). Species importance value index admits a comparison of species in a given location and reflects the occurrence of dominance of a given species in relation to other associated species in the area. Therefore, it is a good index for vegetation characteristics and ranking species for management and conservation priority. In general, species with smaller importance value index need high conservation effort, whereas species with larger IVI need monitoring management [48].

In the current study, the highest IVI was contributed by Syzygium guineense(62) and the least was by Capparis micrantha (0.13). Juniperus procera was reported to have the highest proportion of IVI [24]. Syzygium guineense with high IVI value (Table 8) depicts that the species sociological structure in the community is high and requires monitoring and management, whereas Capparis micrantha requires high conservation priority.

3.10. Population Structures Woody Species. Population structures of woody species could have vital importance to their conservation, sustainable use, and management. Six representative woody species, namely, Syzygium guineense, Psydrax parviflora, Elaedendron buchananii, Ficus sur, Macaranga capensis, and Maytenus arbutifolia were the selected species with the highest IVI based on the quantitative data of woody species structure. There are many environmental factors which may tend to influence population structure of individual plant species including the nature of soil, altitude, climate, human disturbance and disturbance by free grazing and browsing domestic animals, which may affect seedling establishment and survival of woody plant species of the forests. The population structure of woody species in Wurg forest was examined in terms of the number of individuals in a different DBH class distribution. The study showed that different plant species display various population structures. The analysis of woody species of the forest recognized four major patterns of population structures (Figure 8).

3.10.1. Bell-Shaped Distribution. Characterized by few number of individuals in the lowest and highest DBH classes and high number of individuals in middle classes, particularly third DBH class. This could be due to poor reproduction and recruitment potential. Such pattern was exhibited by Macaranga capensis (Figure 8(e)). Other species of the group include Nuxia congesta, Ehretia cymosa, and Prunus africana. The study illustrated a hampered regeneration particularly at initial DBH class that could be linked to various reasons such as requirement of pole sizes for different purposes including fuelwood collection, selective wood harvesting for different purposes, clearing for agriculture, trampling, or grazing by livestock, since almost all species of the group are browsed or influenced by a combination of aforementioned factors. Similar findings were reported from studies in different Afromontane forests of Ethiopia [57, 72, 73],

3.10.2. Inverted J-Shaped Distribution. Characterized by the highest frequency particularly in the lower diameter classes and the number of individuals decreases as DBH increases (Figures 8(b), 8(c), and 8(f)). Theoretically, such trend depicts healthy populations that are naturally replacing themselves through good recruitment. A good regeneration potential of the forests was reported by $[62,63]$. Species of this group have a stable population structure, naturally replacing senesced individuals with seedlings and saplings. However, it should be made clear that some species of this group have natural limit from which they cannot increase in $\mathrm{DBH}$ once they reach a maximum limit such as Maytenus arbutifolia. Other tree species of the group include Ozora 
TABLE 7: Comparison of the basal area of Wurg forest with basal areas of other 10 Afromontane forests in Ethiopia.

\begin{tabular}{|c|c|c|c|c|c|c|c|c|c|c|c|}
\hline Forest & $\mathrm{BT}^{1}$ & $\mathrm{MS}^{2}$ & $\mathrm{GSH}^{3}$ & $\mathrm{MG}^{4}$ & $\mathrm{BM}^{5}$ & $\mathrm{MAG}^{6}$ & $\mathrm{BD}^{7}$ & $\mathrm{BB}^{8}$ & $\mathrm{KD}^{9}$ & $\mathrm{GF}^{10}$ & $\mathrm{WG}^{11}$ \\
\hline $\mathrm{BA} \mathrm{ha}^{-1}$ & 103.5 & 142.6 & 98.9 & 68.5 & 129 & 94.2 & 114.6 & 87.5 & 59.7 & 64 & 126.5 \\
\hline
\end{tabular}

Source, $[30]^{1},[70]^{2},[61]^{3},[59]^{4},[21]^{5},[57]^{6},[24]^{7},[33]^{8},[71]^{9},[49]^{10}$, and the present study ${ }^{11}$. Note. BT, Belete; MS, Masha; GSH, Gelesha; MG, Magada; BM, Bale mountains; MAG, Menna Angetu; BD, Boda; BB, Berebere; KD, Komba-Daga; GF, Guraferda; WG, Wurg.

TABLE 8: The relative density, relative dominance, relative frequency, and important value index of tree/shrub species in Wurg forest.

\begin{tabular}{lccccc}
\hline No & Name of the species & Relative density & Relative dominance & Relative frequency & Important value index \\
\hline 1 & Syzygium guineense & 8.37 & 46.39 & 6.84 & 61.6 \\
2 & Psydrax parviflora & 21.33 & 2.98 & 4.18 & 28.49 \\
3 & Elaedendron buchananii & 9.38 & 10.67 & 6.15 & 26.2 \\
4 & Ficus sur & 0.89 & 9.69 & 1.86 & 24.35 \\
5 & Macaranga capensis & 5.79 & 12.63 & 6.69 & 24.11 \\
6 & Maytenus arbutifolia & 6.76 & 4.27 & 5.92 & 17.75 \\
7 & Oxyanthus speciosus & 16.32 & 2.11 & 4.99 & 12.44 \\
8 & Galiniera saxifraga & 4.9 & 1.21 & 5.34 & 9.98 \\
9 & Maytenus senegalensis & 3.65 & 0.99 & 5.69 & 7.74 \\
10 & Pavetta abyssinica & 1.92 & 0.13 & 46.62 & 76.24 \\
11 & Others & 22.61 & 9.1 & 100 & 300 \\
12 & Total & 100 & 100 & & \\
\hline
\end{tabular}

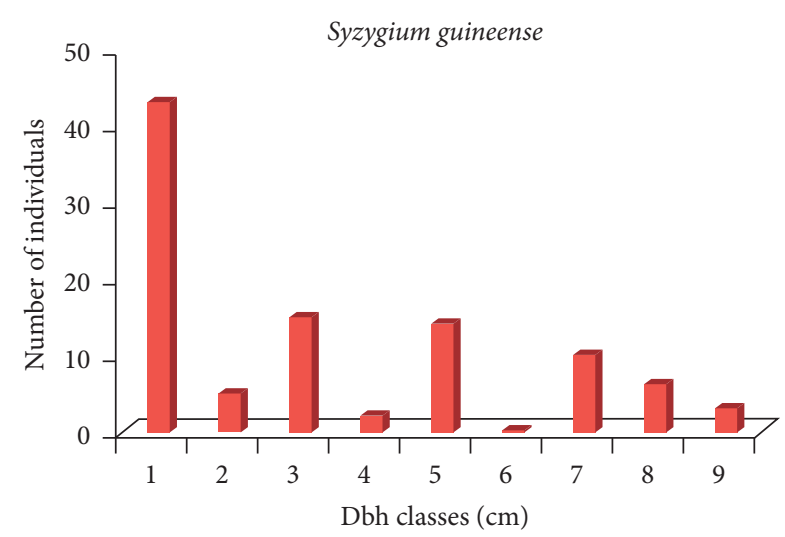

(a)

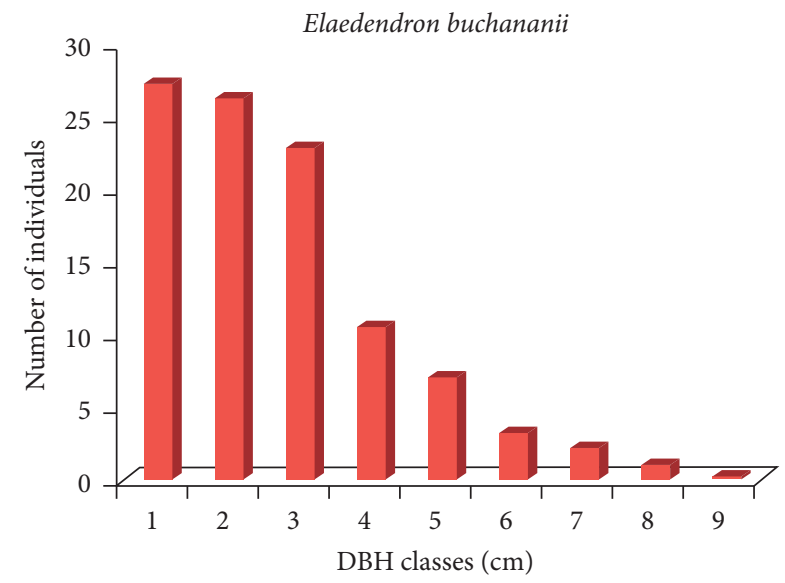

(c)

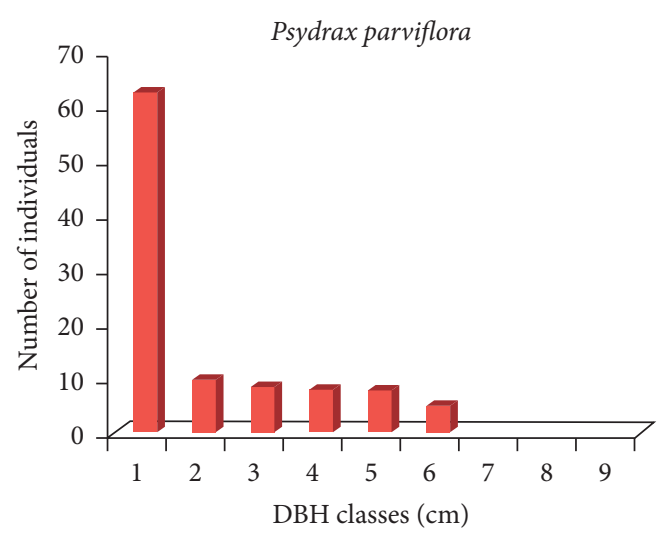

(b)

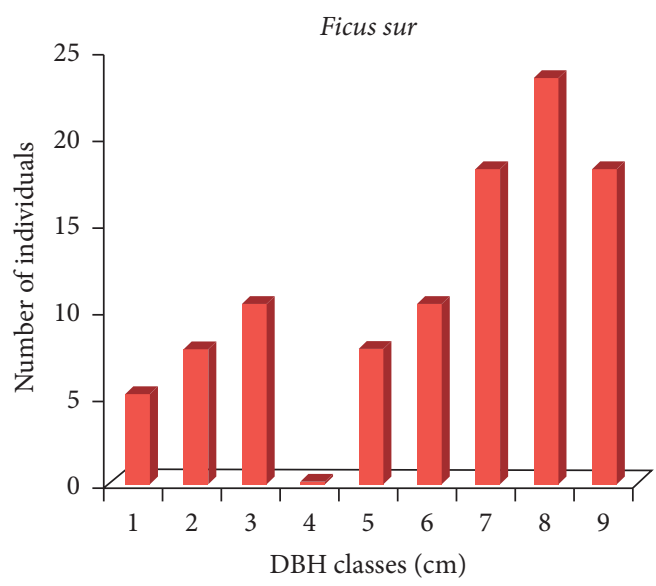

(d)

Figure 8: Continued. 


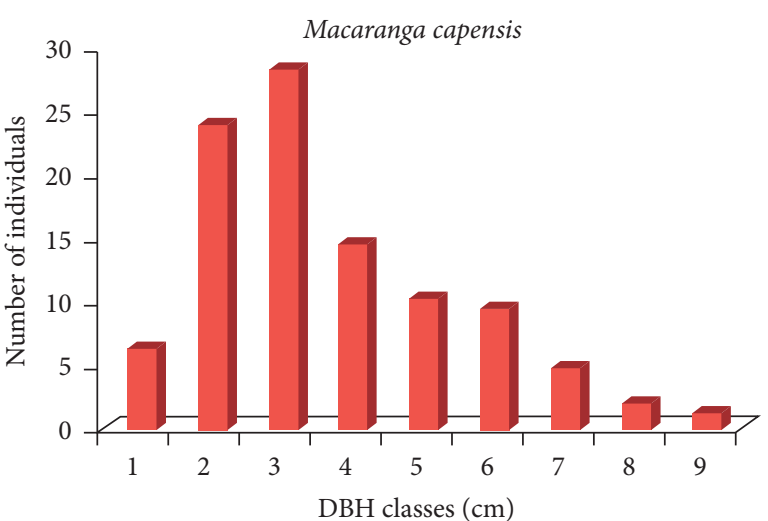

(e)

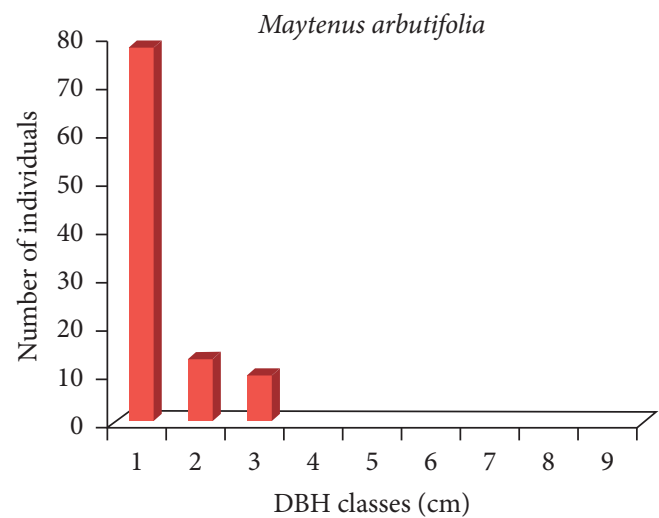

(f)

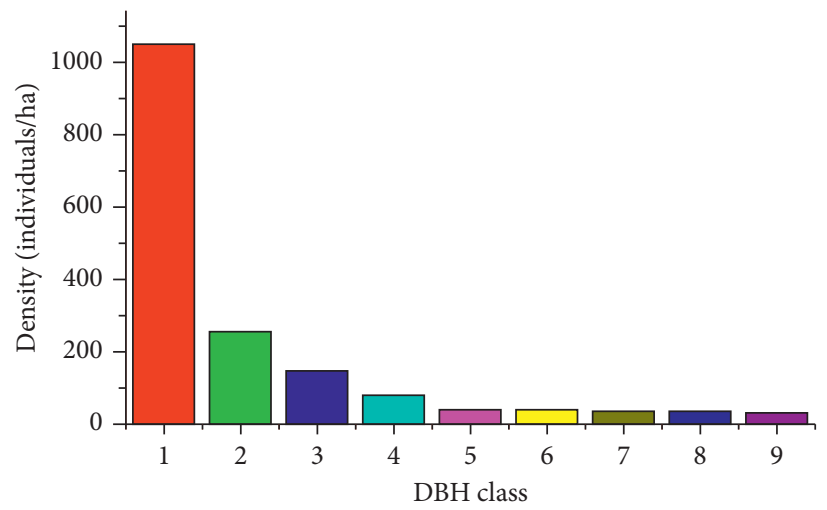

(g)

Figure 8: Population structures of representative species (a)-(f) and the overall pattern of population structure of Wurg forest (g): class 1 $(2.5-12.5 \mathrm{~cm}), 2(12.6-22.5 \mathrm{~cm}), 3(22.6-32.5 \mathrm{~cm}), 4(32.6-42.5 \mathrm{~cm}), 5(42.6-52.5 \mathrm{~cm}), 6(52.6-62.5 \mathrm{~cm}), 7(62.6-72.5 \mathrm{~cm}), 8(72.6-82.5 \mathrm{~cm})$, and $9>(82.5 \mathrm{~cm})$.

insignis, Schefflera volkensii, Bersama abyssinica, Vepris dainellii, and Allophylus abyssinica.

\subsubsection{Broken Inverted J-Shaped Distribution.} Characterized by very low number of individuals in the higher $\mathrm{DBH}$ classes, which gradually decreases towards the highest $\mathrm{DBH}$ class with missing individuals in the middle $\mathrm{DBH}$ classes (Figure 8(a)), e.g., Syzygium guineense, which may be due to selective cutting for various purposes, including household tool making in rural areas. In contrast to this finding, another study [68] reported Syzygium guineense to have the J-shaped type of frequency distribution from Afromontane forests of Ethiopia indicating a low number of individuals in the lower diameter classes, which increases towards the higher classes. On the other hand, other workers [32] reported a bell-shaped structure of Syzygium guineense from south central part of Ethiopia where middle $\mathrm{DBH}$ classes had relatively higher number of individuals than the lower and top classes. This also depicts that the disturbance type and intensity may influence the population structure of a particular species in different localities.

3.10.4. Broken J-Shaped Distribution. Characterized by low number of individuals at the lower classes and gradually increasing towards the higher $\mathrm{DBH}$ class distribution but no individuals somewhere in the middle e.g., Ficus sur (Figure $8(\mathrm{~d})$ ). Such species have relatively weak regeneration and damage caused by selective cutting at certain DBH classes in the middle, indicating high conservation importance. One study [68] discussed that $J$-shaped patterns show poor reproduction and hampered regeneration of the forest species that is attributed to either most trees are not producing seeds due to age or there have been losses due to predating animals after reproduction. In general, the overall population structure of tree/shrub species of Wurg forest has a good regeneration status where there are large number of individuals at lower $\mathrm{DBH}$ class and few in upper $\mathrm{DBH}$ distribution class (Figure 8(g)), which indicates that the contribution of seedlings to the total population was the highest followed by saplings and adult trees. It can be stated that regeneration of woody species in the forest was "good" probably favored by the prevailing environmental factors, and the future plant communities may be sustained unless there is any major environmental stress or interference exerted by human activities.

3.11. Regeneration Status of the Forest. The composition and density of seedling, sapling, and adult woody plants species were used to determine the regeneration status of Wurg forest (Table 9). The total density of seedling, sapling, and 
TABle 9: Regeneration status of tree/shrub species of Wurg forest.

\begin{tabular}{|c|c|c|}
\hline $\begin{array}{l}\text { Good regeneration (seedling > sapling }>\text { tree } \\
\text { shrub) }\end{array}$ & $\begin{array}{l}\text { No regeneration (no seedling and } \\
\text { sapling at all) }\end{array}$ & $\begin{array}{c}\text { Fair regeneration (seedling }>\text { or } \leq \text { sapling } \leq \text { tree/ } \\
\text { shrub) }\end{array}$ \\
\hline $\begin{array}{l}\text { Allophylus abyssinica } \\
\text { Bersama abyssinica } \\
\text { Brucea antidysentrica. } \\
\text { Calpurnia aurea } \\
\text { Capparis micrantha } \\
\text { Carissa spinarum } \\
\text { Canthium oligocarpum } \\
\text { Coffea Arabica } \\
\text { Dracaena fragrans } \\
\text { Elaedendron buchananii } \\
\text { Grewia ferruginea } \\
\text { Hypericum revolutum } \\
\text { Maesa lanceolata } \\
\text { Maytenus arbutifolia } \\
\text { Maytenus senegalensis } \\
\text { Millettia ferruginea } \\
\text { Myrsine africana } \\
\text { Nuxia congesta } \\
\text { Olinia rochetiana } \\
\text { Osyrise quadripartita } \\
\text { Oxyanthus speciosus subsp. globosus } \\
\text { Phoenix reclinata } \\
\text { Phytolacca dodecandra } \\
\text { Psydrax parviflora } \\
\text { Rhamnus staddo } \\
\text { Rhamnus prinoides } \\
\text { Rhus vulgaris } \\
\text { Clerodendrum myricoides } \\
\text { Rubus apetalus } \\
\text { Vepris dainellii } \\
\text { Vernonia auriculifera } \\
\text { Vernonia bipotini } \\
\text { Vernonia myriantha } \\
\text { Olea europea L. subsp. Cuspidata }\end{array}$ & $\begin{array}{c}\text { Buddleja polystachya } \\
\text { Cordia africana } \\
\text { Diospyros abyssinica } \\
\text { Euphorbia ampliphylla } \\
\text { Ficus sur } \\
\text { Ozora insignis } \\
\text { Polyscias fulva } \\
\text { Sapium ellipticum } \\
\text { Schefflera abyssinica } \\
\text { Prunus africana }\end{array}$ & $\begin{array}{l}\text { Albizia schimperiana } \\
\text { Clausena anisata } \\
\text { Clutia abyssinica } \\
\text { Dracaena steudneri } \\
\text { Ehretia cymosa } \\
\text { Ocimum lamiifolium } \\
\text { Pavetta abyssinica } \\
\text { Rhus glutinosa } \\
\text { Vernonia leopoldi } \\
\text { Syzygium guineense } \\
\text { Vernonia amygdalina } \\
\text { Olea welwitschii } \\
\text { Macaranga capensis } \\
\text { Bridelia micrantha } \\
\text { Dombeya torrida } \\
\text { Galiniera saxifraga } \\
\text { Poor regeneration } \\
\text { Pavetta oliveriana } \\
\text { Pittosporum viridiflorum } \\
\text { Premna schimperi } \\
\text { Schefflera volkensii }\end{array}$ \\
\hline
\end{tabular}

adult trees/shrubs was $4966.07 \mathrm{ha}^{-1}$ (50.48\%), $3125.78 \mathrm{ha}^{-1}$ $(31.78 \%)$, and $1745.27 \mathrm{ha}^{-1}(17.74 \%)$, respectively. The total report of seedlings, saplings, and trees/shrubs from Chilimo-Gaji forest of central highland was $1743.75 \mathrm{ha}^{-1}$, $827.08 \mathrm{ha}^{-1}$. and $757.64 \mathrm{ha}^{-1}$, respectively [55], but another study [74] described $5081.3 \mathrm{ha}^{-1}, \quad 1537.5 \mathrm{ha}^{-1}$, and $514.5 \mathrm{ha}^{-1}$ seedlings, saplings, and trees, respectively, showing a good regeneration status of the study forest that might be associated with limited disturbance of the forest and the agroclimatic condition of the SW part of the country. Previous workers [46] discussed that the regeneration behavior of woody species in a forest can be divulged from the population structure, since the population structure of the natural regeneration pattern is mutually related to each other. But the regeneration status of a particular forest can be examined by the comparison of saplings and seedlings with mature trees. The general pattern of seedling, sapling, and matured trees/shrubs indicates that the currently studied forest is in a good regeneration, and reproduction potential of seedling$>$ sapling $>$ adult is as described by [75]. Similar result was reported by [30] from Belete moist evergreen montane forest from southwestern Ethiopia.

Out of the identified 76 trees and shrub species, 10 species, namely, Schefflera abyssinica, Prunus africana, Sapium ellipticum, Ficus sur, Polyscias fulva, Cordia africana, Ozora insignis, Euphorbia ampliphylla, Diospyros abyssinica, and Buddleja polystachya, had no seedling and sapling at all (only in mature stage), and 3 species, namely, Bridelia micrantha, Olea welwitschii, and Vernonia amygdalina, had only seedling and matured species, and 4 species, namely, Schefflera volkensii, Premna schimperi, Pittosporum viridiflorum, and Pavetta oliveriana, were found only at the sapling and matured stages. Generally, five regeneration levels were recognized in the study forest, namely, $50.8 \%$ species were in good regeneration; $23.8 \%$ species were in fair regeneration; $6.0 \%$ species were in poor regeneration; $14.9 \%$ had no regeneration; and $4.5 \%$ species were only in seedling/sapling. However, researchers [55] have reported $26 \%$ good regeneration, $43 \%$ fair regeneration, $7 \%$ poor regeneration, $7 \%$ lacked regeneration, and $17 \%$ have appeared as newly regenerating, indicating that 
TABle 10: Density distribution of woody species in Wurg forest by the story.

\begin{tabular}{|c|c|c|c|c|c|c|}
\hline Story & No. of individual & Density $(A)$ & Percentage & No. of species $(B)$ & Percentage & Ratio $(A / B)$ \\
\hline Lower $(<11.55 \mathrm{~m})$ & 3251 & 1269.92 & 72.76 & 62 & 96.88 & 20.48 \\
\hline Middle $(11.55-23.1 \mathrm{~m})$ & 963 & 376.17 & 21.55 & 20 & 32.25 & 18.81 \\
\hline Upper (>23.1 m) & 254 & 99.22 & 5.68 & 9 & 14.06 & 11.02 \\
\hline
\end{tabular}

Wurg forest had far better regeneration status than Chilimo-Gaji forest of central Ethiopia that might be linked with the level of disturbance.

3.12. Vertical Structure. According to IUFRO classification scheme, three vertical structures were distinguished in tropical forests. These are upper story (tree height $>2 / 3$ of top height), middle story (tree height between $1 / 3$ and $2 / 3$ of top height), and lower story ( $<1 / 3$ of top height). Accordingly, the top height in Wurg forest was represented by Ficus sur, $35 \mathrm{~m}$, and the distribution is given in Table 10 .

According to [26], the structure of upper story heights plays a significant role in shaping different microenvironments that ultimately determine conditions that limit beneath the plant growth. The vertical organization of the plant community can be resulted from recruitment, growth, and competition of the environmental factors. In the vertical stratification, Wurg forest had large numbers of individuals at the lower story, and the lower story contains almost all species (97\%). Similar result was reported from Gergeda Anfillo forest [76], Bonga and Maji forests [68], and Komatsu Afromontane forest [29] in western Ethiopia, in which only few species attained the upper story. The low abundance or low density of the canopy tree species could be linked with anthropogenic influences in the past other than the climatic condition of the area. Some species exist in both the upper and lower/middle story. Some of the species that covered the upper story or the canopy layer were Syzygium guineense, Elaedendron buchananii, Macaranga capensis, Ficus sur, Allophylus abyssinicus, Nuxia congesta, Euphorbia ampliphylla, Vepris dainellii, and Schefflera abyssinica.

\section{Conclusion and Recommendation}

4.1. Conclusion. Wurg forest has relatively rich diversity of woody species (76 species), and high species diversity and evenness values as compared to many of Afromontane forests of Ethiopia. Four plant community types were identified by cluster analysis using the presence/absence value of each species in each plot. Both $\mathrm{DBH}$ and height class distribution showed that the density of individuals decreases with increasing $\mathrm{DBH}$ and height class. The ratio of density of $\mathrm{DBH}>10 \mathrm{~cm}$ to $\mathrm{DBH}>20 \mathrm{~cm}$ showed that Wurg forest has good regeneration capacity and experienced relatively little impact by the local people. The most frequent tree species was Syzygium guineense, which is similar to Masha forest probably due to its geographic proximity to the study area. Likewise, the measure of the relative importance of species in Wurg forest had relatively larger number, almost similar to Masha forest that might be because of the geographic location of the two forests. Syzygium guineense, Maytenus arbutifolia, and
Elaedendron buchananii were the dominant tree/shrub species of Wurg forest. Although in general, Wurg forest showed an inverted $J$-shaped population structure with good regeneration capacity, this study depicted 4 different population structures of different species in the forest (broken inverted $J$-shaped, inverted $J$-shaped, broken $J$ shaped, and bell-shaped structures). Generally, five regeneration statuses were recognized in Wurg forest, of which more than $50 \%$ were in a good regeneration status, which probably depicts existence of limited disturbance of the forest.

4.2. Recommendations. Based on the findings of the current study forest, the following recommendations are more significant for the sustainability of the forest biodiversity and livelihood of the local community in general.

(1) Promote community awareness raising programs through extension programs about the use of forest resource and looking for options for community's livelihoods to minimize their dependence on the forest

(2) Encouraging private and community forest plantation at the district level by the Office of the Environment, Forest, and Climate Change, and Office of Agriculture, so that farmers will be benefitted from their own resource and minimizing the impact on the existing natural forests

(3) Ethnobotanical study of the forest is required to explore the wealth of indigenous knowledge on the diversity of plants and promote forest conservation

(4) A detailed ecological study of the forest is required with the emphasis on looking for the methods of propagating ecologically and economically useful species with no seedling and sapling, and those woody species with no regeneration. This may include the investigation of soil seed bank for such species.

\section{Data Availability}

The data used to support the findings of this study are available from the corresponding author upon request.

\section{Conflicts of Interest}

The authors declare that they have no conflicts of interest.

\section{Acknowledgments}

The authors deeply acknowledge Dilla University and Maji Woreda for material and financial support rendered to 
accomplish the study. The authors also thank Tum correction institute for material support and copying questionnaires for data collection. Moreover, the authors wish to express their deepest gratitude to Siski Kebele community for their wonderful support in data collection. They would also deeply thank the Ethiopian Biodiversity Institute for helping in the identification of plant species.

\section{References}

[1] EBI (Ethiopian Biodiversity Institute), National Biodiversity Strategy and Action Plan 2015-2020, EBI (Ethiopian Biodiversity Institute), Addis Ababa, Ethipoia, 2015.

[2] I. Friis, S. Demissew, and P. van Breugel, Atlas of the Potential Vegetation of Ethiopia, Det Kongelige Dan Ske Videnskabernes Selskab, Copenhagen, Denmark, 2010.

[3] EWNHS (Ethiopian Wildlife and Natural History Society), Important Bird Areas of Ethiopia: A First Inventory, EWNHS, Addis Ababa, Ethipoia, 1996.

[4] E. Kelbessa and S. Demissew, "Diversity of vascular taxa of the flora of Ethiopia and Eritrea," Ethiopian Journal of Sciences and Sustainable Development, vol. 13, pp. 37-45, 2014.

[5] EFAP, The Challenge for Development. Ethiopian Forestry Action Program, EFAP, Addis Ababa, Ethiopia, 1994.

[6] M. Reusing, "Change detection of natural high forests in Ethiopia using remote sensing and GIS techniques," International Archives of Photogrammetry and Remote Sensing, vol. 33, pp. 1253-1258, 2000.

[7] MEFCC (Ministry of Environment), Legal and Institutional Framework for the Ethiopian REDD+ Program, Ministry of Environment, Addis Ababa, Ethiopia, 2015.

[8] Z. Mekonnen and A. Nigatu, "Woody plant diversity in a disturbed secondary forest and river course vegetation at eastern bases of abaro mountain, wondo genet southern Ethiopia," World Research Journal of Biology and Biological Sciences, vol. 1, no. 1, pp. 1-9, 2013.

[9] B. Bishaw, "Deforestation and land degradation in the Ethiopian highlands: a strategy for physical recovery," Ethiopian e-Journal for Research and Innovation Foresight, vol. 1, no. 1, pp. 5-18, 2009.

[10] K. Anitha, S. Joseph, R. J. Chandran, E. V. Ramasamy, and S. N. Prasad, "Tree species diversity and community composition in a human-dominated tropical forest of western ghats biodiversity hotspot, India," Ecological Complexity, vol. 7, no. 2, pp. 217-224, 2010.

[11] M. Lemenih and H. Kassa, "Re-greening Ethiopia: history, challenges and lessons," Forests, vol. 5, no. 8, pp. 1896-1909, 2014.

[12] M. Debeenhoulwer, B. Oosterlynk, M. Vanopstel et al., Express Diversity Survey in Sheka Forest Biosphere Reserve: Ethiopia Biodiversity Express Survey 5 Biodiversity Inventory for Conservation, Glabbek Belgium and Deme, Zwijndrecht, Belgium, 2016.

[13] K. Yeshitela and T. Bekele, "Plant community analysis and ecology of the afromontane and transitional rainforest vegetations of the south western Ethiopia," SINET Ethiopian Journal of Science, vol. 25, no. 2, pp. 155-175, 2002.

[14] S. Shibru and G. Balcha, "Compostion structure and regeneration status of woody plant species in didin natural forest, south east Ethiopia: an implication for conservation," Ethiopian Journal of Biological Sciences, vol. 3, pp. 5-55, 2004.
[15] D. Teketay, "Seed and regeneration ecology in dry afromontane forests of Ethiopia: seed production population structure," Tropical Ecology, vol. 46, pp. 29-44, 2005.

[16] A. Tilahun, T. Soromessa, E. Kelbessa et al., "Floristic compostion and community analysis of menagesha amba mariam forest (edgu forest) in central Ethiopia," Ethiopian Journal of Biological Sciences, vol. 10, pp. 111-136, 2011.

[17] A. F. Pappoe, E. Armah, E. C. Quaye et al., "Composition and stand structure of a tropical moist semi deciduous forest in Ghana," International Research Journal of Plant Science, vol. 1, pp. 95-106, 2010.

[18] T. Bekele, "Vegetation ecology of remnant afromontane forests on the central plateau of shewa, Ethiopia," Acta Phytogeographica Suecica, vol. 79, pp. 1-58, 1993.

[19] S. Demissew, "A study of the vegetation and floristic composition of southern wello, Ethiopia," Journal of Ethiopian Studies, vol. 31, no. 1, pp. 159-192, 1998.

[20] K. Yeshitela and T. Bekele, "Woody species composition of masha anderach forest south western Ethiopia," Ethiopian Journal of Biological Sciences, vol. 2, pp. 31-48, 2003.

[21] K. Hundera, T. Bekele, and E. Kelbessa, "Floristic and phytogeography synopsis of a dry afromontane coniferous forest in the bale mountains (Ethiopia): implications to biodiversity conservation," SINET: Ethiopian Journal of Science, vol. 30, no. 1, pp. 1-12, 2007.

[22] T. W. Mariam, T. Borch, M. Dinich, and D. Teketay, "Floristic composition and environmental factors characterizing coffee forest in south west Ethiopia," Forest Ecology and Management, vol. 255, pp. 2138-2150, 2008.

[23] F. Senbeta and D. Teketay, "Diversity community types and population structures of woody plants in kinche forest, a virgin nature reserve in southern Ethiopia," Ethiopian Journal of Biological Sciences, vol. 2, no. 2, pp. 169-187, 2003.

[24] F. Erenso, M. Maryo, and W. Abebe, "Floristic composition, diversity and vegetation structure of woody plant communities in boda dry evergreen montane forest, west shewa, Ethiopia," International Journal of Constitutional Law, vol. 6, no. 5, pp. 382-391, 2014.

[25] D. Unbushe and T. Tekle, "Floristic composition and diversity of woody plant species of wotagisho forest, boloso sore woreda wolaita zone south west Ethiopia," International Journal of Natural Resource Ecology and Management, vol. 1, no. 3, pp. 63-70, 2016.

[26] T. Bekele, "Phytosociology and ecology of a humid afromontane forest on the central plateau of Ethiopia," Journal of Vegetation Science, vol. 5, no. 1, pp. 87-98, 1994.

[27] T. Soromessa, D. Teketay, and S. Demissew, "Ecological study of the vegetations in gamo gofa zone, southern Ethiopia," Journal of Tropical Ecology, vol. 45, pp. 209-221, 2004.

[28] A. Ayalew, T. Bekele, and S. Demissew, "The undifferentiated afromontane forest of denkoro in the central highland of Ethiopia: a floristic and structural analysis," SINET: Ethiopian Journal of Science, vol. 29, no. 1, pp. 45-56, 2006.

[29] F. Gurmessa, T. Soromessa, and E. Kelbessa, "Structure and regeneration status of komto afromontane moist forest, east wollega zone, west Ethiopia," Journal of Forestry Research, vol. 23, no. 2, pp. 205-216, 2012.

[30] K. Gebrehiwot and K. Hundera, "Species composition, plant community structure and natural regeneration status of belete moist evergreen montane forest, oromia regional state, southwestern Ethiopia," Momona Ethiopian Journal of Science, vol. 6, no. 1, pp. 97-101, 2014.

[31] D. Edae and T. Soromessa, "Comparative analysis of structure and regeneration status of woody species in managed and 
community used forests sites in gelesha kebele ,mejenger forest ,gambella regional state," Palgo Journal of Agriculture, vol. 3, no. 1, pp. 111-131, 2016.

[32] M. Bekele and W. Abebe, "Floristic composition and vegetation structure of woody plant species in lambo natural forest in tembaro woreda, kambata tambaro zone southern Ethiopia," American Journal of Agriculture and Forestry, vol. 4, no. 2, pp. 49-55, 2016.

[33] T. Bogale, D. Datiko, and S. Belachew, "Structure and regeneration status of woody plants of berbere moist afromontane forest, bale zone, south east Ethiopia ;implication to biodiversity conservation," Open Journal of Forestry, vol. 7, pp. 352-371, 2017.

[34] M. Woldearegay, Z. Woldu, and E. Lulekal, "Species diversity, population structure and regeneration status of woody plants in yegof dry afromontane forest, north eastern Ethiopia," European Journal of Advanced Research in Biological and Life Sciences, vol. 6, no. 4, pp. 2056-5984, 2018.

[35] B. Maji, Zone Socio-Economic Geospatial Data Analysis and Dissemination Core Process, Annual Statistical Abstract, Addis Ababa, Ethiopia, 2016.

[36] M. Mwardo, Woreda Agricultural and Rural Development Office Annual Report, WoARD, Addis Ababa, Ethiopia, 2016.

[37] Y. Mihret and L. Yohannes, "Site suitability evaluation of ecotourism potential for sustainable natural resource management and community based ecotourism development: in the case of bench maji zone, south western part of Ethiopia," Social Science and Humanities Journal, vol. 3, no. 8, pp. 1368-1383, 2015.

[38] I. Friis, F. Rasmussen, and K. Vollesen, "Studies in the flora and vegetations of southwest Ethiopia," Opera Botanica, vol. 63, pp. 8-70, 1992.

[39] J. Hilliman, "Ethiopia compendim of wild life conservation information," 1993.

[40] D. Dana, "Conservation status of bird fauna of south west of omo national park," International Journal of Biodiversity and Conversation, vol. 10, no. 6, 2018.

[41] F. Senbeta, "Biodiversity and ecology of afromontane rain forest with wild Coffea arabica 1. population in Ethiopia" Ph.D. thesis, University of Bonn, Bonn, Germany, 2006.

[42] D. Muller-Dombois and H. Ellenberg, "Aims and methods of vegetation ecology: community sampling the relieve method," 1974.

[43] R. Singhal, Soil and Vegetation Studies in Forests, ICFRE Publications, Dehra Dun. India, 1996.

[44] W. Venables and D. Smith, An Introduction to R: Notes on R: A Programming Environment for Data Analysis and Graphics, Network Theory Ltd., London, UK, 2012.

[45] M. Kent and P. Coker, Vegetation Description and Analysis, A practical Approach, John Wiley \& Sons, New York City, NY, USA, 1992.

[46] A. K. Saxena and J. S. Singh, "Tree population structure of certain himalayan forest associations and implications concerning their future composition," Vegetatio, vol. 58, no. 2, pp. 61-69, 1984.

[47] P. Chauhan, J. Negi, L. Singh, and R. Manhas, "Regeneration status of sal forests of doon valley," Annals of Forestry, vol. 16, pp. 178-182, 2008.

[48] H. Lamprecht, Silvi Culture in the Tropics.Tropical Forest Ecosystems and Their Tree Species-Possibilities and Methods for Their Long-Term Utilization, Deutsche Gesellschaft Für Internationale Zusammenarbeit, Bonn, Germany, 1989.

[49] K. Hundera and B. Deboch, "Woody species composition and structure of gurra farda forest, SNNPR, south west Ethiopia,"
Ethiopian Journal of Education and Science, vol. 2, pp. 44-54, 2008.

[50] M. Gedafaw and T. Soromessa, "Status and woody plant species diversity in tara gedam forest, north Ethiopia," Science, Technology and Arts Research Journal, vol. 3, no. 2, pp. 113118, 2014.

[51] M. Girma and M. Maryo, "The diversity and composition of woody plants in chebera churcura national park (ccnp), southern Ethiopia," Open Journal of Forestry, vol. 8, no. 4, pp. 439-458, 2018.

[52] J. Vivero, E. Kelbessa, and S. Demissew, "Progress on the red lists plants of ethiopia and eritrea: conservation and biogeography of endemic plant taxa," in Taxonomy and Ecology of African Plants, Their Conservation and Sustainable Use, S. A. Ghazanfar and H. Beentje, Eds., The Royal Botanic Garden Sydney, Sydney, Australia, pp. 761-778, 2006.

[53] A. Ayanaw and G. Dalle, "Woody species diversity, structure, and regeneration status of yemrehane kirstos church forest of lasta woreda, north wollo zone, amhara region, Ethiopia," International Journal of Forestry Research, vol. 2008, Article ID 5302523, 8 pages, 2008.

[54] A. E. Magurran, Measuring Biological Diversity, BlackWell, Oxford, UK, 2004.

[55] M. Siraj and K. Zhang, "Structure and natural regeneration of woody species at central highlands of Ethiopia," Journal of Ecology and the Natural Environmen, vol. 10, pp. 147-158, 2018.

[56] P. J. Grubb, J. R. Lloyd, T. D. Pennington, and T. Whitmore, "A comparison of montane and lowland rain forest in Ecuador I: the forest structure, physiognomy, and floristics," The Journal of Ecology, vol. 51, no. 3, pp. 567-601, 1963.

[57] E. Lulekal, E. Kelbessa, and T. Bekele, "Plant species composition and structure of the mana angetu moist montane forest, south-eastern Ethiopia," Journal of East African Natural History, vol. 97, no. 2, pp. 165-185, 2008.

[58] F. Yineger, "Remnant vegetation and vegetation structures of jima forest western Ethiopia," M.S. thesis, Addis Ababa University, Addis Ababa, Ethiopia, 2008.

[59] G. Bekele and P. R. Ramachandra, "Structure analysis and population structures of the vegetation of magada forest, borena zone, oromia, Ethiopia," International Journal of Asian Academic Research Associates, vol. 1, no. 28, pp. 2319-2801, 2014.

[60] B. Kebede, T. Soromessa, and E. Kelbessa, "Structure and regeneration status of gedo dry evergreen montane forest, west shewa zone of oromia national regional state, central Ethiopia," Science, Technology and Arts Research Journal, vol. 3, no. 2, pp. 119-131, 2014.

[61] B. Alemu, K. Hundera, and B. Abera, "Floristic composition and structural analysis of gelesha forest, gambella regional states south west Ethiopia," Journal of Ecology and the Natural Environment, vol. 17, no. 7, pp. 218-227, 2015.

[62] A. Wassie, D. Teketay, and N. Powell, "Church forests in the north gondar administrative zones," Forest Tree and Lively Hoods, vol. 15, pp. 55-74, 2005.

[63] G. Tesfaye, D. Teketay, M. Fetene, and E. Beck, "Regeneration of seven indigenous tree species in a dry afromontane forest, southern Ethiopia," Flora-Morphology, Distribution, Functional Ecology of Plants, vol. 205, no. 2, pp. 135-143, 2010.

[64] E. Kelbessa and T. Soromessa, "Interface of regeneration, structure, diversity and use of some plant species in bonga forest: a reservoir for wild coffee gene pool," SINET: Ethiopian Journal of Science, vol. 31, no. 2, pp. 121-134, 2008. 
[65] L. Kidane, T. Bekele, and S. Nimomissa, Vegetation Compostion in Hugumbirda-Gartskhasu National Foresrt Priority Area, South Tigray, Mekelle University, Mek'ele, Ethiopia, 2010.

[66] A. Berta, "Vegetation composition and deforestation impact in gambella national park, Ethiopia," Journal of Natural Resources and Development, vol. 5, no. 3, pp. 30-36, 2016.

[67] A. Bekele, Useful trees of Ethiopia: Identification, Propagation and Management in 17 Agroecological Zones, ICRAF, Nairobi, Kenya, 2007.

[68] F. Senbeta, "An analysis of vegetation structure of the moist evergreen afromontane forests of Ethiopia," Ethiopian Journal of Applied Science and Technology, vol. 7, pp. 37-50, 2016.

[69] European Environment Agency, "European forest types: categories and types for sustainable forest management and reporting," Technical Report, European Environment Agency, Copenhagen, Denmark, 2006.

[70] A. Assefa, S. Demissew, and Z. Woldu, "Floristic composition, structure and regeneration status of masha forest, south-west Ethiopia," African Journal of Ecology, vol. 52, no. 2, pp. 151-162, 2013.

[71] K. Kidane, K. Hundera, and G. Dalle, "Species diversity and structural analysis of komba daga moist moist evergreen forest, kaffa zone, south west Ethiopia: a research and reviews," American Journal of Life Sciences, vol. 5, no. 3, pp. 2348-9545, 2015.

[72] D. Teketay, "Seedling populations and regeneration of woody species in dry afromontane forests of Ethiopia," Forest Ecology and Management, vol. 98, no. 2, pp. 149-165, 1997.

[73] G. Tesfaye, D. Teketay, and M. Fetene, "Regeneration of fourteen tree species in harenna forest, southeastern Ethiopia," Flora: Morphology, Distribution, Functional Ecology of Plants, vol. 197, no. 6, pp. 461-474, 2002.

[74] G. Gebeyehu, T. Soromessa, T. Bekele, and D. Teketay, "Species composition, stand structure, and regeneration status of tree species in dry afromontane forests of awi zone, northwestern Ethiopia," Ecosystem Health and Sustainability, vol. 5, no. 1, pp. 199-215, 2019.

[75] P. Saikia and M. Khan, "Population structure and regeneration status of Aquilaria malaccensis lam. in homegardens of upper Assam, northeast India," Tropical Ecology, vol. 54, pp. 1-13, 2013.

[76] D. Raga and A. Seid, "Vegetation structure and floristic composition of gergeda anfillo forest, west Ethiopia," Ethiopian Journal of Science and Technology, vol. 10, no. 2, pp. 137-150, 2017. 